\title{
LEXICOSTRATIGRAPHY: TRACING GEOGRAPHICAL LOCATION AND LINGUISTIC CHANGE IN KORING
}

\author{
Linda Chinelo Nkamigbo* \\ http://dx.doi.org/10.4314/og.v9i1.6
}

\section{Abstract}

Lexicostratigraphy is an aspect of historical linguistics that makes use of interlingual borrowings in determining the original settlers of a given speech environment. This paper explores this theoretical framework in an attempt to determine the original settlers in Ebonyi state, southeastern Nigeria. The two groups of people being investigated are the Oring people numbering less than three hundred thousand and the Igbo people with a numerical strength of about fifteen million. The Oring and Igbo people speak Koring and Igbo respectively. The two groups occupy the southeastern geopolitical zone in Nigeria but their languages belong to different language families within the Benue-Congo phylum. Koring belongs to the East Benue-Congo while Igbo belongs to the West BenueCongo. Borrowings were used for two purposes. Firstly, to determine the Oring settlement; then, to examine linguistic change in Koring. An investigation of the two languages' lexical items revealed that the Oring were the first to settle in their present location. This study also showed that the two languages' contact has resulted in Koring lexical change.

\section{Introduction}

This paper tries to examine word histories using the theoretical framework of lexicostratigraphy. Ehret (2000) ascertains that word histories in a language or a group of languages can be uncovered through the establishment of a linguistic 
stratigraphy. He goes further to claim that the most basic form of such a stratigraphy can be represented by a family tree of relationships among the languages being studied. In lexicostratigraphy, the histories are established by examining lexical items. Lexicostratigraphy, according to Eze (2007), "seeks to discover interlingual borrowings so as to employ the findings in making some deductions of historiographical nature of both a linguistic kind and those relating to other aspects of social life." It relies on lexicons obtained from the actual speech acts of the languages under investigation. In this paper, borrowings were used for two purposes. Firstly, to determine the Oring settlement; then, to examine linguistic change in Koring.

The Oring settlement has been a great source of puzzle to scholars. Cook (1935) made some speculations about the origin of the Oring, though he did not reach a categorical conclusion. Talbot (1969) claimed that the Oring were the first to settle in the area where they now cohabit with the Igbo in southeastern Nigeria. He went further to assert that the Igbo might have joined the Oring later but being greater in number, they subdued the Oring through constant fights. This compelled some of the Oring to look for new settlements farther north and farther south with non-Igbo ethnic groups as neighbours. Although there is no linguistic evidence or the lore of the Oring to support Talbot's conclusion, the work is more or less pioneering for tracing the Oring settlement.

This paper explores the lexicostratigraphic framework in an effort to determine the original settlers in Ebonyi state, southeastern Nigeria. The two groups of people being investigated are the Oring people numbering less than three hundred thousand and the Igbo people with a numerical strength of about fifteen million. The Oring speak the Koring language while Igbo is the language of the Igbo people. The 
Linda Nkamigbo: Tracing the Geographic Location and Linguistic Change in Koring

Oring and the Igbo occupy the Southeastern geopolitical zone in Nigeria but their languages belong to different language families within the Benue-Congo phylum. Koring belongs to the East Benue-Congo while Igbo belongs to the West BenueCongo (see Williamson and Blench, 2000). Igbo is spoken in the core Igbo states: Abia, Anambra, Ebonyi, Enugu and Imo while Koring is basically spoken in Ebonyi state and some parts of Benue and Cross-River states of Nigeria. Koring is a minority language whose use is geographically localized and functionally restricted and whose number of speakers is declining.

Eze (2007) examined Ezza dialect of Igbo, Ntezi and Okpoto dialects of Koring using one hundred lexical items which were randomly selected and claimed that the Igbo were the first settlers in Ebonyi state. This present study investigated Ezza and standard dialects of Igbo, and Okpoto dialect of Koring using Roger Blench's one thousand wordlist and came up with the claim that the Oring were the first to settle in their present location. This study also examined the old and younger generations of Oring and observed that large numbers of the lexical items in use by the younger generation were borrowed from Igbo. Figure 1 below is a map showing Koring-speaking communities in Ebonyi state of Nigeria. 


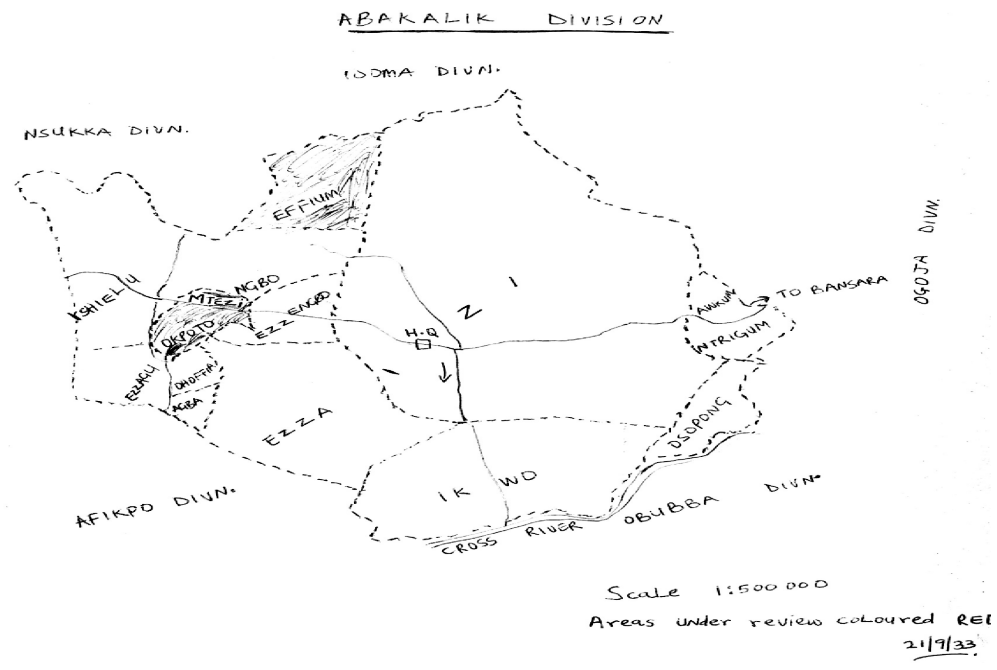

Figure 1: Map showing Koring-speaking communities in Ebonyi state of Nigeria.

\section{Research Questions}

This paper tends to answer the questions according to Newman (2000:269):

Who borrowed from whom?

What adjustments took place in accepting the loan words?

What impact did the loan words have on the recipient language?

\section{The Language Data}

The items for this study are arranged under five categories according to their semantic and social values thus:

religion (rl)

human relations $(\mathrm{hr})$

time (tm)

nutrition (nt) 
Linda Nkamigbo: Tracing the Geographic Location and Linguistic Change in Koring art/craft/manufacture (acm)

\subsection{Tracing Oring location through interlingual borrowings}

The Koring expressions that have Igbo cognaticity are the items or practices that came through the Oring's contact with the Igbo. Basically, the relevant expressions fall under rl, hr, $\mathrm{tm}$, nt and acm. The following lexical items entered the Koring language through its contact with Igbo.

Lexical items under the heading 'religion' are as follows:

a. ibinukpabi: supreme deity in Arochukwu

b. ofo: kind, symbol of uprightness

c. aliobu:

shrine of the homestead

d. aguma/ekpe:

a type of mask dance by a secret all-male society

e. uka: church

Lexical items under the heading 'human relations' are as follows:
a. kogbasa
to dismiss, rise as in a meeting or end a session as in a church or school
b. uro
slave
c. kobo money
d. kafia market

Lexical items under the heading 'time' are as follows:
a. Eke
first day of the traditional week
b. Ode second day of the traditional week
c. Afo
third day of the traditional week
d. Okwo fourth day of the traditional week 
Lexical items under the heading 'nutrition' are as follows:
a. ereshi
rice
b. alumu
orange
c. ube
pear
d. okere
groundnut
e. abi
a kind of yam

Lexical items under the heading 'art/craft/manufacture' are as follows:
a. icha
soap
b. egbirigba
bell
c. lopi
flute
d. igada
a kind of chair

a-d under religion entered the Koring language as a result of the Aro influence. Eze (2007: 49) observes that Aro influence in Southeastern Nigeria co-originated with the trans-Atlantic slave trade. They were the middlemen for the European dealers and employed a combination of tactics one of which was a deception based on presenting themselves as the children of an all-powerful and all-knowing deity ruling the universe. Those who offended this deity were presumed killed by him. But the truth is that through an arcane device, undiscovered by the clients but known to every member of a pan-Aro all-male secret society, such victims were sold to European slave buyers. Practices from the Aro's part of the southernmosteastern districts of the Igbo country were also spread to their sphere of economic influence.

With the stability in the Aro strategy they met no resistance among the Oring who were only too willing to adjust their language and social organisation to suit the group who presented themselves as and whom the hosts accepted as the "children of God" (Ojike nd: 14). 'uka' came through the 
contact with Europeans and their Igbo agents. Ekejiuba (1972:21) observes in a different context that the Aro further restructured the Igbo four-day cycle: Eke, Orie, Afo and Nkwo, which the Oring borrowed and adjusted to: Eke, Ode, Afo and Okwo. The Oring's reason for borrowing the four-day cycle was to enable them transact business with the Aro. In order to transact business with the Aro, knowledge of the Igbo week days was very crucial. Although the Oring were farmers, they were not growing rice. Rice farming came with the advent of the Igbo. All other items under hr, nt and acm came with the Igbo.

It is not in doubt that Koring borrowed extensively from Igbo (cf. Eze, 2007). Some lexical items examined for this present study have been observed to exist in Igbo neighbouring languages such as Yoruba but not in Koring neighbouring languages. It is therefore pertinent to state that the recipient language speakers are the original settlers of the land while the donor language speakers arrived later. In affirmation of my claim, Ehret (2000:280) asserts,

“... a very large number of words may have been borrowed. Very often this kind of word borrowing tells us that large numbers of the people who spoke the donor language of the loan words were assimilated into the society of the people who adopted the words".

\subsection{Linguistic change in Koring}

Languages undergo change through language contact and this is mostly done by younger speakers. Michael (2006) notes that the younger generation is the part of society which is most exposed to intense language changes. Lexical change is most evident in the speeches of younger Koring speakers. Here, I am going to discuss those words that were originally Koring 
Ogirisi: a new journal of African studies vol 92012

words but due to the influence of Igbo, younger Koring generation adopts the Igbo names for those lexical items. Some instances of lexical change observed in Koring are as follows:

$\begin{array}{lll}\text { Old speakers } & \text { Young speakers } & \text { Gloss } \\ \text { likun } & \text { ugwu } & \text { hill } \\ \text { okpanwono } & \text { umunne } & \text { relations } \\ \text { olum } & \text { eze } & \text { king } \\ \text { otin } & \text { chineke } & \text { God } \\ \text { loboro } & \text { ugwu } & \text { respect } \\ \text { uphua } & \text { uru } & \text { profit } \\ \text { otum } & \text { ochie } & \text { old } \\ \text { kere } & \text { osisi } & \text { tree } \\ \text { lisiseofu } & \text { etum } & \text { dust } \\ \text { keyan } & \text { okwu } & \text { word } \\ \text { liyese } & \text { obodo } & \text { town } \\ \text { lewegbanyi } & \text { ide } & \text { flood } \\ \text { ara } & \text { papa } & \text { father } \\ \text { olele } & \text { iwe } & \text { anger } \\ \text { koyira } & \text { nkwa } & \text { promise } \\ \text { nowom } & \text { aguu } & \text { hunger } \\ \text { lowu } & \text { kobo } & \text { money } \\ \text { kekun } & \text { iba } & \text { malaria } \\ \text { lalonwo } & \text { ugwo } & \text { eczema } \\ \text { kokpokbo } & \text { ozodimgba } & \text { gorilla } \\ \text { ilagwa } & \text { nne nwaanyi } & \text { woman }\end{array}$

It should be noted that lexicons of the younger speakers are all words from the Igbo language.

The influence of Igbo on Koring is outrageous. Igbo is used for formal gatherings and not Koring. Igbo is used by mass media; Bible readings are done in Igbo and not in Koring. Igbo is used as a medium of instruction in schools. 
Linda Nkamigbo: Tracing the Geographic Location and Linguistic Change in Koring Koring is only used in informal discourse. It is also observed that rural-urban drift is highly affecting the Koring language.

\section{Summary and Conclusion}

This study investigated Ezza and standard dialects of Igbo, and Okpoto dialect of Koring using Roger Blench's one thousand wordlist. The findings showed that the Oring were the first to settle in Ebonyi state of Nigeria, though they adjusted linguistically and socially to suit their strangers. However, the Koring language is under increasing threat by Igbo. Koring is no longer passed down to younger generation and the younger Koring generation shifts to Igbo. The older generation sees bilingualism in Igbo and Koring as essential. The economic way of life of the Oring was also affected. The Oring, who were renowned in farming, are now involved in trade as the Igbo.

The Ezza dialect of Igbo spoken in Ebonyi state is somewhat unintelligible to a vast majority of Igbo speakers. Hence, the Ezza people joined the Oring and the contact resulted in the corrupt form of the Ezza Igbo. A great number of Ezza lexical items differ from those of Standard Igbo. For instance,

$\begin{array}{lll}\text { Ezza Igbo } & \text { Standard Igbo } & \text { English Gloss } \\ \text { ma } & \text { mmuo } & \text { ghost } \\ \text { nshi } & \text { obere } & \text { small } \\ \text { mboku } & \text { ubochi } & \text { day } \\ \text { ogerenya } & \text { okenye } & \text { elder } \\ \text { maju } & \text { mmadu } & \text { human being } \\ \text { uhu } & \text { ulo } & \text { house }\end{array}$

This study also examined the old and younger generations of Oring and observed that a large number of the lexical items in 
Ogirisi: a new journal of African studies vol 92012

use by the younger generation were borrowed from Igbo. It is noteworthy that the influence of Igbo on Koring is massive. It is now the Language of the Immediate Community, placing Koring on an endangered status. Some Oring communities such as Izem, Eteji and Lame were given Igbo names Amuda, Ntezi and Okpoto respectively after being assimilated by the Ezza Igbo.

*Linda Chinelo Nkamigbo is a Lecturer in the Department of Linguistics, Nnamdi Azikiwe University, Awka 
Linda Nkamigbo: Tracing the Geographic Location and Linguistic Change in Koring

\section{References}

Cook, A.E. (1935). 'Intelligence report on Mtezi and Okpoto clans of Abakaliki division of Ogoja province'. An unpublished report retrieved from the National Archives Enugu, Nigeria, dated January 5.

Ehret, Christopher. (2000). 'Language and history', in Bernd Heine and Derek Nurse, (eds.), African Languages: An Introduction. Cambridge: Cambridge University Press, 272-297.

Ekejiuba, Ifeoma. (1972). 'The Aro system of trade in the nineteenth century'. Ikenga. Vol. 1, no. 1, 11-26.

Eze, P.J., (2007). 'Lexicostratigraphy, historical linguistics and historiography', in B.N. Anasiudu, G.I. Nwaozuzu and C.N. Okebalama, (eds.), Language and Literature in a Developing Country: Essays in Honour of Professor Benson O.A. Oluikpe. Onitsha: Africana-First Publishers Limited, 42-63.

Michael, E.W. (2006). 'Language change and language shift: The challenging factors to linguistic diversity from the perspective of Ethiopian minorities'. A paper presented at the $5^{\text {th }}$ World Congress of African Linguistics held at the Addis Ababa University, Ethiopia in August.

Newman, Paul. (2000). 'Comparative linguistics', in Bernd Heine and Derek Nurse, (eds.), African Languages: An Introduction. Cambridge: Cambridge University Press, 259-271.

Ojike, Mbonu. (n.d.). My Africa, Lagos: Stevebond Press.

Talbot, P.A. (1969). The Peoples of Southern Nigeria, London: Frank Cass \& Company.

Williamson, Kay \& Roger Blench. (2000). 'Niger-Congo', in Bernd Heine and Derek Nurse, (eds.), African Languages: An Introduction. Cambridge: Cambridge University Press, 11-42. 